\title{
Development of Short Movie as Instructional Media to Teach Present Tenses
}

\author{
P D Degeng ${ }^{1}$, F Unsiah ${ }^{2}$, I N Kusumawardani. ${ }^{3}$, M H Isnaini ${ }^{4}$ \\ Universitas Brawijaya
}

\{1dian_degeng@ub.ac.id, ${ }^{2}$ frida_unsiah@ub.ac.id, ${ }^{3}$ irene.nany@ub.ac.id, ${ }^{4}$ hasbullah_hazee@ub.ac.id\}

\begin{abstract}
The development of a short movie entitled "Present Moments" intends to assist English Lecturers to teach English Grammar. It is also based on the fact that the lecturers often find difficulties in explaining the basic concept of grammar and providing concrete examples to the students as English foreign learners. Thus, these facts trigger the researchers to develop a movie as instructional media to teach English Tenses especially Present Tenses. The present research used ADDIE development model. The product is a short movie in DVD format about teaching Present Tenses especially for students who are taking English grammar class in Faculty of Cultural Studies Universitas Brawijaya, Indonesia. This product was validated by media expert and content expert. Questionnaires were used as the instruments to collect the data. The researchers analyzed the data obtained from the media and content experts by describing and categorizing all of the information into comments and suggestions. The result of the validation from the content expert shows that the movie is considered appropriate as instructional media. However, it still needs improvement especially the quality of the pictures. Meanwhile, the result of the validation from the content expert shows that the movie can be used as instructional media but it still needs some revisions. Suggestion for further research is the use of Present Tenses in the scenes of the movie should be more elaborated and optimized.
\end{abstract}

Keywords: Development, Movie as Instructional Media, Present Tenses, ADDIE Model Development

\section{INTRODUCTION}

The teaching of English grammar which focuses on the tenses or time create confusion among students when they learn the grammar of their mother tongue which is Bahasa Indonesia. The difference between the two languages causes difficulties for the teacher and students, even in the context of higher education. However, the differences cannot be avoided because there are some fundamental differences among languages in this world. In English, the use of verb is likely influenced by the type of time and activity itself which is significantly different from Bahasa Indonesia Grammar in which the form of the verb does not depend on the time and activity. For instance, the verb "makan" in Bahasa Indonesia will make no change when it is used in different timeline: "Kemarin saya makan nasi goreng."; "Setiap pagi saya makan nasi goreng. "; "Besok saya akan makan nasi goreng." If those sentences are changed into English, 
there will be significant changes on the verb "eat": "Yesterday I ate fried rice."; "Every morning I eat fried rice."; "Tomorrow, I will eat fried rice.", Furthermore, the English timeline has its time and activities such as simple, continuous, perfect and the combination of perfect and continuous. In the context of Bahasa Indonesia, all verb is always in the form of present, like the word "makan". However, in the context of English the form of the verb changes according to the tense use, such as daily activities is in the form present, the ongoing activity at the time of speaking is in the form continuous, the activity which has been done is in the form perfect, and the activity which has been done but still in the progress should be in the form of perfect continuous.

The teaching of grammar in higher education still uses the conventional method such as giving the formula of the tenses and providing examples . however, the lecturers experience some difficulties in teaching grammar, especially when it comes to giving the concrete examples of the grammar use being learnt. Moreover, the differences between the first and target language in concept make things even more difficult for the students. The lack of media uses to picture the concept of grammar triggers the development of the movie as the potential media in grammar teaching, especially the present tenses concept.

For the past few years, movie has been proved to be an effective media in an implicit teaching because these sets of complex scenes can take the viewers to the realm exposed in it. Moreover, students, nowadays, are exposed to the technology such as smartphone and tablets which make them feel not enough to read from the printed version of books and urge the more technology-friendly media.

Based on the result of the previous movie development entitled "Pengembangan Video Pembelajaran untuk Pengajaran English Tenses", the researcher get some appreciation and feedback to develop another film as media in teaching grammar which focus on the Present Tenses. It is crucial to design the teaching of grammar based on the cluster tenses to make it easier to teach and use it. Thus, the present research is focus on the development of short movie in the teaching of present tenses which cover the past, present, and future tenses and present which indicates future. There are two prominent objectives of the present study. First, it is expected that the movie will help the English lecturers, especially those who teach Grammar focusing on the concept of present tense and the use of it in a formal or informal spoken and written communication. Second, the movie is expected to be a helpful tool for english students to understand the concept of present tense better. Third, the movie development will help the english students to improve their understanding about various kind of grammar teaching methods since they are trained to be teachers.

In Indonesia, English is considered as a foreign language which is learned after first and second language acquisition. English is difficult to learnt although Bahasa Indonesia (Indonesian language) and English have the same orthography in which both of them use the same alphabet. However, English has a different way of pronouncing words from Bahasa Indonesia which makes English difficult for Indonesian learners to master. One of prominent scholars who are expert in understanding a language acquisition especially in second language and foreign language states that there are two independent systems in acquiring a second language [1]. The first system is called "the acquired system" that is a product from a natural process which is similar to how children acquire their first language. The second system is called "the learned system" that is a product from a formal learning in a class where learners and teachers meet in order to learn a language. The learning activity is arranged in order to bring a teaching learning process out with the purpose of learning a desired language.

In line with [1], [2] also argues that grammar is an important language component to support learners in mastering a language. He [2] states that there is a universal rule in a second language 
acquisition which is called Universal Grammar. Chomsky and his fellow scientists claim that grammar mastery is very important in the second language acquisition process. An initial knowledge about an understanding of a language which is called Language Faculty is a component of human mind, which is located within a brain and a part of congenital condition of a species [2]. Anything that a language has in common is called Universal Grammar. In 1970s, the disciples of this approach assumed that a language acquisition cannot be separated from a child understanding about a system of a language that is going to be absorbed. Thus, they believe that grammar is very important for language learners if they want to master a language they learn.

Grammar is a very important component to booster English skills because grammar competence of an individual will determine how accurate they use English. Grammar is a part of learning about a structure of a language [3]. The structure here means a sentence structure that lies in a language. Basically, Grammar attempts to outline how a form of a language can be accepted so that it is important for learners to learn forms of Grammar of a language in order to facilitate them in understanding the meaning of sentences in a language.

One of grammar forms that are required to be mastered by language learners is tenses. Tenses are forms of time in English which explain about when things happen so that it gives more accurate information. There are several techniques that can be used in learning tenses such as silent time, reading aloud, correction [4]. Silent time is an activity undertaken to give learners time to ponder the tenses structure in order to deepen their understanding. Reading aloud is the second activity that can be done in learning tenses which aims to train learners to comprehend tenses that have been learned so that they can absorb them well. The last activity is correction as editing. In learning grammar, learners surely make mistakes in the process. As an instructor or a teacher, we are demanded to always give sympathy to learners by giving kinds of feedback such as correction, revision with explanation about mistakes made by learners during grammar learning process.

Learning grammar, especially tenses, is an activity which is quite boring for learners. In this case, a tool is needed to help the process of learning tenses. One that can be used is media. The use of media as a tool for learning grammar is able to facilitate the teaching and learning process done by teachers. The success of learning grammar may not only be obtained by applying several techniques, but also using media to make language learning more fun.

Movie is an artwork and a culture which is a see-listen mass communication medium made based on the cinematography principles recorded in a celluloid tape, video tape, video disc, and/or other technology discovery materials in any forms, kinds, and sizes through chemical, electronic, or other processes with or without sound, which can be presented and/or displayed with mechanical projection systems, electronics, etc [5]. In short, movie is one of see-listen mass communication media which can be presented. When movie is used for the teaching and learning in a class, it is considered as an instructional media. The use of movie as an instructional media has been considerably implemented in the digital era nowadays.

The transformation of how learners study demands teachers to be more creative and innovative in teaching learning process in a class. The ways learners learn in digital era are more into technology based learning [6]. All information that can be accessed through technology has greater chance to be absorbed by learners. This fact thus makes movie become popular as an instructional media. Movie development for instructional media is highly recommended [7]. Sandhya and Bhuvaneswari [8] also reveal that the use of instructional media can promote better environment for learning process. There are several advantages of using movie as an effective learning, such as movie can overcome time and space (time and space manipulation); portray events realistically in a short period; deliver messages which are usually easy to remember; 
clarify abstract instances by giving realistic illustration; give strong impact to learners when it is played repeatedly; be suitable for various learners' characteristics.

\subsection{Research Method}

Model development used in this research was ADDIE (Analysis, Design, Development, Implementation, Evaluation) model [9]. Analysis. Based on the previous product evaluation and discussion with all related parties, it was found that the materials given was too general and each tenses could not be explained clearly. Thus, the next product developed focus on one specific tenses, so that it could be used for all students who are interested in learning English Grammar. Design and development. Product developed is in form of a short movie entitled "Present Moments" for the students who are taking English class in Faculty of Cultural Studies, Universitas Brawijaya. Implementation and evaluation. The product validation was done by media and content experts. Product dissemination was not done because of time limitation. Instrument used was questionnaires for the experts. Descriptive analysis used to analyze the data which in form of comments and suggestions.

\subsection{Result and Discussion}

The short movie "Present Moments" was tested by two experts: media expert and content expert. The data resulted from the first evaluation (through questionnaire) is in qualitative. Some components are regarded to connect to these aspects: form, sound, music, narration (script), editing. The result is presented on the following table:

Table 1. Media Expert Validation's Result.

\begin{tabular}{|c|c|c|c|}
\hline Aspect & Indicator & Yes/ No & Comment/Suggestion \\
\hline \multirow[t]{2}{*}{ Form } & 1. Credits on the CD/DVD's cover & Yes & \\
\hline & 2. CD/DVD' Hard Case & Yes & \\
\hline \multirow[t]{7}{*}{ Sound } & 1. Clear voices & Yes & \\
\hline & 2. Clear articulation & No & \\
\hline & 3. Movie uses informative dialogue & Yes & Some words of Mr. \\
\hline & (movie over) & Yes & Hamdan are \\
\hline & $\begin{array}{l}\text { 4. Movie uses general terms and } \\
\text { instructional }\end{array}$ & Yes & $\begin{array}{l}\text { pronounced less } \\
\text { clearly }\end{array}$ \\
\hline & $\begin{array}{l}\text { 5. The words/vocabulary used is on the } \\
\text { same level of the learners }\end{array}$ & Yes & \\
\hline & 6. Communicative language & & \\
\hline \multirow[t]{4}{*}{ Music } & 1. Instrumental (backsound) & Yes & \\
\hline & 2. Low volume (backsound) & Yes & Too loud for learning \\
\hline & 3. Contextual music/backsound & No & process \\
\hline & 4. Music credits & No & \\
\hline \multirow[t]{4}{*}{ Narration } & $\begin{array}{l}\text { 1. Narration is compatible with } \\
\text { learning objectives }\end{array}$ & No & $\begin{array}{l}\text { - Too much } \\
\text { narration }\end{array}$ \\
\hline & 2. Narration elaborates present tenses & No & - Lack of tenses' \\
\hline & 3. Clear intonation & Yes & explanation \\
\hline & 4. Compatible plot & No & $\begin{array}{l}\text { The beginning } \\
\text { scene is not in line } \\
\text { with the script }\end{array}$ \\
\hline
\end{tabular}


Editing

1. 5-20 minutes length

No

Yes

3. Entertaining, attractive, educating, Yes stimulating

The second questionnaire also resulted in qualitative data. The components were evaluated towards their compatibility to Present Tenses. The result is presented below:

Table 2. Content Expert Validation's Result.

\begin{tabular}{|c|c|c|c|}
\hline Aspect & Indicators & $\begin{array}{c}\text { Yes/ } \\
\text { No }\end{array}$ & Comments/Suggestion \\
\hline $\begin{array}{c}\text { Materia } \\
I\end{array}$ & $\begin{array}{l}\text { 1. Equivalent with learning outcomes } \\
\text { 2. Material is explained in sequence } \\
\text { 3. Material is delivered from easy to } \\
\text { hard level } \\
\text { 4. Material is presented appropriately } \\
\text { and comprehensively } \\
\text { 5. Material considers the learner needs } \\
\text { 6. References of information/material }\end{array}$ & $\begin{array}{l}\text { Yes } \\
\text { No } \\
\text { No } \\
\text { No } \\
\text { Yes } \\
\text { Yes }\end{array}$ & $\begin{array}{l}\text { - The material presented in } \\
\text { the movie is } \\
\text { incomprehensible } \\
\text { - There are many scenes that } \\
\text { not relevant with the } \\
\text { material } \\
\text { - Material should be match } \\
\text { with the scenes to make it } \\
\text { relevant. }\end{array}$ \\
\hline
\end{tabular}

The short movie "Present Moments" is comprised into total 32 minutes 25 seconds and is recorded on DVD cassette with MP4 format. It also has cover and hardcase as it is usually found in other movie's DVD. There are screenshoots, credits and summary of the movie on the cover. This movie is made to be media to learn English tenses, especially to comprehend the present tenses (present simple, present continuous, present perfect, and present perfect continuous) for college students in early semester.

Harmer (2004) explains that movie as instructional media has some benefits. First, movie accommodates the learner's need to comprehend the target language by presenting them through movie scenes in everyday conversation context. "Present Moments" tells about an English teacher named Mr. Hamdan. The life story of Mr. Hamdan is mostly about his teaching activity to Indonesian students in early semester of college. The plot focuses to his discussion about English tenses, more precisely, present tenses. However, his Indonesian students still face the same trouble in comprehending the concept of tenses, though they had been learning English for years. After his conversation with his wife, Mr. Hamdan inwardly looks into his conventional teaching method in delivering the explanation. He then decides to change his teaching styles to become more creative and innovative. Some ways that suits the millennials.

The second benefit of movie is that, it is able to provide fun and entertaining media for language learners because they do not only watch but also hear the movie scenes wrapped in interesting plot. Through this activity, audiences absorb many elements in the movie and they unconsciously learn many things. By inserting some lesson and explanation about English grammar inside the plot and scenes, the movie media aims to entertain and educate the students in the same time.

Third, the use of movie as instructional media also suits the learner's characteristic in digital era, in which, teachers are required to innovate their ways of teaching more creatively inside classroom. The digital era closely related to technology development. The issue is also brought up inside the movie "Present Moments" where Mr. Hamdan uses the social media to teach grammar. All information is easily accessed through technology, and this hold large part of 
millennials' life. By utilizing the technology for instructional media, this movie is very suitable for the learners' need characteristics.

\section{CONCLUSIONS}

Based on the result of validation by the experts, it can be concluded that even though the short movie is regarded as suitable to be utilized inside the classroom to teach grammar, it needs many improvements. Some of the revisions that can be done are related to the quality of the basic elements of movie themselves, including the scene, sound, shots, etc. The property and devices needed should be prepared in advance also the choice of the actors and crews. Regarding to the use of the media in the classroom, the students still need to be assisted and to watch they are required the movie several times to comprehend the lesson. Lastly, the identification of each present tense shall be added to ease the audience in watching the movie. Additional interactive scenes shall also be considered in the next project to expand the level of comprehension of the learners.

\section{REFERENCES}

[1] S. D. Krashen, Principles and practice in second language acquisition. Pergamon, 1982.

[2] N. Chomsky, "Language and Mind, Third Edition," p. 209.

[3] "how-to-teach-grammar-scott-thornbury.pdf.".

[4] G. Gerngross, H. Puchta, and S. Thornbury, Teaching Grammar Creatively with CD-ROM. Cambridge University Press, 2006.

[5] “uu-33_2009-perfilman.pdf.".

[6] E. Kreutner, The Grammar Movie Project. Research-publishing, 2015.

[7] J. Harmer, The Practice of English Language Teaching. Longman, 1991.

[8] G. Sandhya and D. V. Bhuvaneswari, "Grammar and Style in Media Language," vol. 2, p. $10,2014$.

[9] “ADDIE ebook.pdf.". 